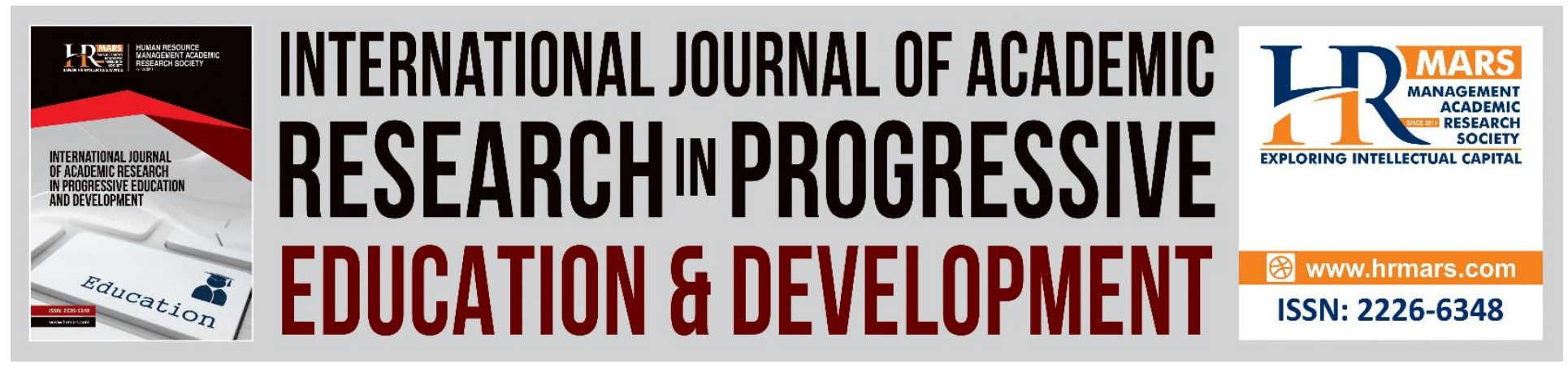

\title{
Mediation Role of Holistic Centered Learning Style in the Relationships of Teachers' Teaching Competency and Students' Academic Achievement
}

Nordiana Mohd Nor, Rahimah Embong, Habsah Muda, Kamariah Yunus, Juliana Mohd Nor

To Link this Article: http://dx.doi.org/10.6007/IJARPED/v8-i1/5598

DOI: $10.6007 /$ IJARPED/v8-i1/5598

Received: 18 Jan 2019, Revised: 23 Feb 2019, Accepted: 18 March 2019

Published Online: 25 March 2019

In-Text Citation: (Nor, Embong, Muda, Yunus, \& Nor, 2019)

To Cite this Article: Nor, N. M., Embong, R., Muda, H., Yunus, K., \& Nor, J. M. (2019). Mediation Role of Holistic Centered Learning Style in the Relationships of Teachers' Teaching Competency and Students' Academic Achievement. International Journal of Academic Research in Business and Social Sciences, 9(2), 114-133.

\section{Copyright: (C) 2019 The Author(s)}

Published by Human Resource Management Academic Research Society (www.hrmars.com)

This article is published under the Creative Commons Attribution (CC BY 4.0) license. Anyone may reproduce, distribute, translate and create derivative works of this article (for both commercial and non-commercial purposes), subject to full attribution to the original publication and authors. The full terms of this license may be seen at: http://creativecommons.org/licences/by/4.0/legalcode

Vol. 8, No. 1, 2019, Pg. 114 - 133

Full Terms \& Conditions of access and use can be found at http://hrmars.com/index.php/pages/detail/publication-ethics 


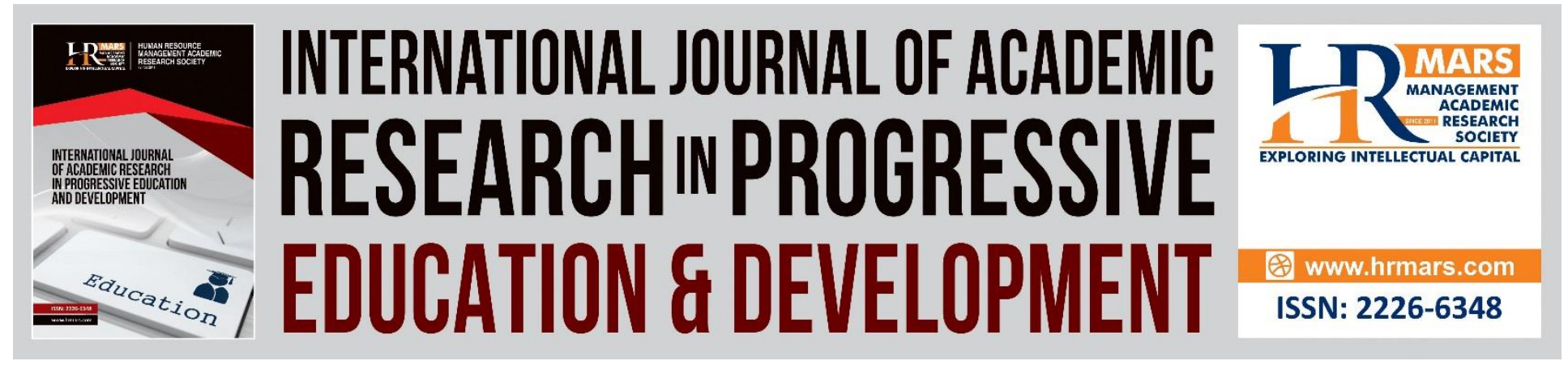

\title{
Mediation Role of Holistic Centered Learning Style in the Relationships of Teachers' Teaching Competency and Students' Academic Achievement
}

\author{
Nordiana Mohd Nor \\ PhD Candidate, Faculty of Islamic Contemporary Studies, Universiti Sultan Zainal Abidin, \\ Malaysia \\ Email: nordianamohdnor@gmail.com
}

Rahimah Embong

Faculty of Islamic Contemporary Studies / Faculty of General Studies \& Advanced Education Universiti Sultan Zainal Abidin, Malaysia

Email: rahimahembong@unisza.edu.my

Habsah Muda

Faculty Economic and Management Science, Universiti Sultan Zainal Abidin, Malaysia

Kamariah Yunus

Faculty of Language and Communication, Universiti Sultan Zainal Abidin, Malaysia

Juliana Mohd Nor

Academy of Language Studies, Universiti Teknologi MARA Terengganu Branch, Malaysia.

\begin{abstract}
The quality of teachers' teaching competence is said to be lacking because they do not have the latest skills and they teach using learning models that are less attractive to students. This paper aims to explore the role of holistic centered learning style ( $\mathrm{HCL})$ in the relationships of teachers' teaching competency and students' academic achievement. $\mathrm{HCL}$ as a new teaching strategy engage students using multiple intelligence learning styles as the educational strategies by focusing student differences in classroom. Teacher is the implementer of all policies and curriculum goals outlined by the government vision. Thus, teachers are the key to the education
\end{abstract}


DEVELOPMENT

Vol. 8, No. 1, 2019, E-ISSN: 2226-6348 ๑ 2019 HRMARS

system. The study employed SEM AMOS quantitative style, research test to develop a model for presenting pedagogical experience in such a way that the teaching skills can be assessed. It is necessary to create a standard of Malaysian teacher competence in teaching to measure knowledge, skills and innovative capacity and productivity that must be achieved in service.

Keywords: Teachers' Teaching Competency, Holistic Centered Learning Style, Student Academic Achievement, Multiple Intelligence, Learning Styles.

\section{INTRODUCTION}

Quality of teachers teaching competence should cover latest education skills and ability to teach using learning models that is attractive to students learning (Jayaron \& Mohammad, 2016). Tradisional teaching practice teachers often use lecture and writing styles in the classroom so that students become less interested and passive in their learning. Therefore, the achievement of the students is also not encouraging. Teachers should be more creative in the learning and teaching process by using teaching skills and applying new styles to attract students. This study need determine the impact of Holistic Centered Learning (HCL) style mediates the relationship between Teacher Competency in teaching skill and student academic performance. Teacher acts as a facilitator in contrast to the instructor. Teachers can lead to positive individual student development. Teachers that are interpersonally oriented, attentive, empathic and fully cognizant of the students' ability, plus believe in the students will produce students who will be extremely positive towards teaching (Chedzoy \& Burden, 2007). This study suggested Holistic Centered Learning which implements multi intelligent learning style as education tools to shift the learning activity from passive to active learner participation; students are facilitated and encouraged by their teacher as facilitators to construct knowledge.

\section{LITERATURE RIVIEW}

\section{Education Of 21 st Century}

A high level of intelligence has always been associated with excellence in academic. Centered Learning is an approach in which teachers, curriculum, teaching, learning, and evaluation focused on students. Difference ability in students are the main focus in this new Holistic-Centered Learning style model research which integrates the uses of seven multi-intelligent proposed by Gardner (1983) and improvised in Memletics Learning Styles Model for secondary school as multiple intelligence learning styles (Whitely S, 2003). Student centered learning are strategies of $21^{\text {st }}$ century skills curriculum (Abdullah, 2004; Aslanian et.al.,2009; Finelli, et.al., 2014; Jayaron \& Mohammad, 2016) include more application of active in learning, hands on and mind on, the cross-disciplinary of inter and trans- nature of teaching that requires changing in learning pattern. Centered learning environment have been proven to be easy, flexible and stimulate to a higher order thinking compared to tradisional learning (Hartini, 2010).

Integration of Holistic-Centered Learning in the classroom as $21^{\text {st }}$-century skills can boost teachers' roles and students' achievement. This is because the Holistic centered learning skills of the 21st century is advantageous in exploring students' multi-intelligent ability in critical thinking, media literacy and knowledge, creativity, communication skills, service learning, problem-based learning, collaborative learning (team based), games and simulation, effective questioning, case study, debates, peer teaching and contextual learning (Katharina, 2016). Success in producing 
DEVELOPMENT

Vol. 8, No. 1, 2019, E-ISSN: 2226-6348 ๑ 2019 HRMARS

teachers with a complete package in education and skills mastery in the 21st century will be beneficial to the students who will be born to meet the industry's needs and in line with the pace of world globalization. Centered Learning has to do with the shifting of learning activity from passive to the active participation of the learners; students are encouraged during the facilitation process by their instructor on the need to construct knowledge (Ssemugabi \& de Villiers (2007); Harashim, (2011)).

Holistic-centered learning is a branch in multiple intelligent learning style that focus on student differences to be active in learning. The $21^{\text {st }}$ century educations skill shift presents more engaging, all-inclusive, and invigorating learning experience and a new environment in which all educators and all students around the world get connected (imel (1991), dirkx \& prenger (1997), slavin (2003), abdullah (2004) aslanian et.al., (2009), katharina (2016) and jayaron \& mohammad (2016).

\section{Teachers' Competencies}

Studies conducted by Abdul Kadir (2002); Pushpalatha (2006); Grove \& Bretz (2007); Tobias et. al. (2009); Hartini (2010); Zamri (2012); Taskinsoy J. (2012); Norazila et al (2010); Katharina (2016); Jayaron \& Mohammad (2016) sees the effects of teaching on student achievement result. Rohaty (2000) found the important of competencies qualities in teacher to explore and always to be develop. Competence skillful teachers can turn out to be attentive, empathic and fully cognisant with the students' ability, as they may likely believe in the student's ability and will make them extremely positive towards learning (Chedzoy \& Burden, 2007). Three factor of teacher competence in teaching are studied in context of planning, developing and result (Murcia et.al., 2015). Planning refers to everything related to the previous process of reflection and design of subject matter (curriculum, the organization of subjects, labs, tutorials, planning of anticipated learning activities, evaluation criteria and styles, teaching materials and resources).The development of the subject teaching involves everything related to the execution of and compliance with the curricula, teaching and learning activities carried out, anticipated pedagogical activities, as well as applied evaluation procedures. And the results, in terms of educational objectives, referring to the achievements made by the students, and to the aspects involving the revision and improvement of teaching activity, external recognition of teaching duties and creation of teaching materials.

\section{Holistic Centered Learning (HCL)}

In this study, the researcher has combined two of the biggest theories of constructivism, i.e. the constructivist theory by Maria Montessori on holistic learning proposed in 1965 which focused on child's development and the cognitive theory by Howard Gardner on multiple intelligences proposed in 1983. These two theories are combined together with Memletic Learning Styles Inventory (Memletic Advanogy, 2015), elaborated by Sean Whiteley, adapted to be the basis for the HCL approach. Seven different learning styles and abilities are recognized by this inventory in accordance with seven kinds of intelligence indicated by Gardner in 1983: verbal (linguistic), visual, aural, logical and physical and with regard to our relations with others, solitary and social 
Vol. 8, No. 1, 2019, E-ISSN: 2226-6348 @ 2019 HRMARS

learning styles (Zajac, 2009). Therefore, in this study, the researcher pursues to define $\mathrm{HCL}$ as a teaching strategy for teachers in engaging students using multiple intelligences learning styles as the educational tools to develop continuous engagement in active classroom construction, focusing on learning modalities for student excellent performance in academic.

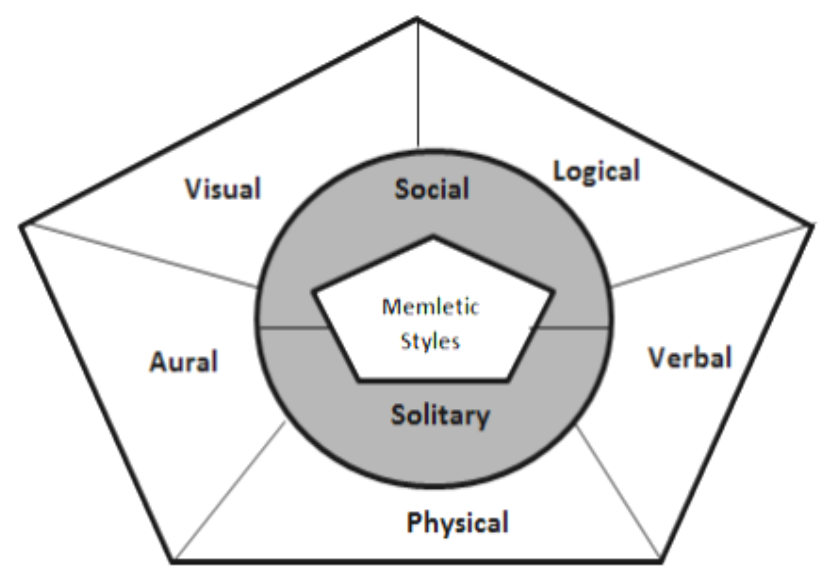

Figure 1: Memletic learning styles combine with multi intelligence

(Source:http://www.learning-styles-online.com/overview/)

\section{Student Achievement}

In the study student performance that will be accessed is academic performances as defined:

First factor are Academic Achievement: A measurement of academic performance, teacher gives grades and GPA on the level of student achievement. Grades are composite measures that account not only for students' content mastery, but often for other factors, such as their class participation, attitudes, progress over time, and attendance (Guzman, 2003). Researcher is using Schools GPA SPM 2015 and 2016 Result in Terengganu state as the result marker due to excellent achievement throughout a decade.

\section{PROBLEM STATEMENT}

This paper aims to explore the role of holistic centered learning style (HCL) in the relationships of teachers' teaching competency and students' academic achievement. 
INTERNATIONAL JOURNAL OF ACADEMIC RESEARCH IN PROGRESSIVE EDUCATION AND

DEVELOPMENT

Vol. 8, No. 1, 2019, E-ISSN: $2226-6348 @ 2019$ HRMARS

Research Question (RQ), Research Objective (RO) and Hypothesis

Table 1:Data analysis RQ, RO and Hypothesis.

\begin{tabular}{|c|c|c|c|c|}
\hline Research Question & Research Objective & Hypothesis & $\begin{array}{l}\text { Analysis } \\
\text { Style }\end{array}$ & $\begin{array}{l}\text { Summary } \\
\text { Analysis }\end{array}$ \\
\hline $\begin{array}{l}\text { Do Holistic } \text { Centered } \\
\text { Learning style } \\
\text { mediates the } \\
\text { relationship between } \\
\text { teacher competencies } \\
\text { and student academic } \\
\text { performance?. }\end{array}$ & $\begin{array}{lr}\text { To identify } & \text { whether } \\
\text { Holistic } & \text { Centered } \\
\text { Learning } & \text { style } \\
\text { mediates } & \text { the } \\
\text { relationship between } \\
\text { teacher competencies } \\
\text { and student academic } \\
\text { performance. }\end{array}$ & $\begin{array}{l}\text { H4: Holistic } \\
\text { Centered Learning } \\
\text { style mediates the } \\
\text { relationship } \\
\text { between teacher } \\
\text { competencies and } \\
\text { student academic } \\
\text { performance. }\end{array}$ & $\begin{array}{l}\text { Path } \\
\text { Analys } \\
\text { is SEM } \\
\text { AMOS }\end{array}$ & $\begin{array}{l}\text { AVE. } 0.5 \\
r=1 \\
\text { Report } \\
\text { Significant } \\
\text { Correlation } \\
r=1 \\
R^{2}=0.00-1.00 \\
\text { T-Test }=\beta=0.8\end{array}$ \\
\hline
\end{tabular}

\section{SIGNIFICANCE OF THE STUDY}

The advantages of an education based on student-centered learning by implementing the multiple intelligence modalities theories (Gardner,1983) and Memletic learning styles (Whiteley S., 2003) forming Holistic Centered Learning Style (HCL) in helping teachers to rethink and adapt their teaching competencies in line with current global needs. $\mathrm{HCL}$ can be educational tools to develop continuous engagement in active classroom construction, focusing on learning modalities for excellent student performance in academic. The research also to test a develop sem model in instructive knowledge that the teaching skills can be evaluated.

\section{MEDIATOR}

Holistic centered learning style as mediator in the conceptual framework of the research. Mediator variable may be said to function as a mediator to the extent that it accounts for the relation between the predictor and the criterion (Baron \& Kenny (1986).

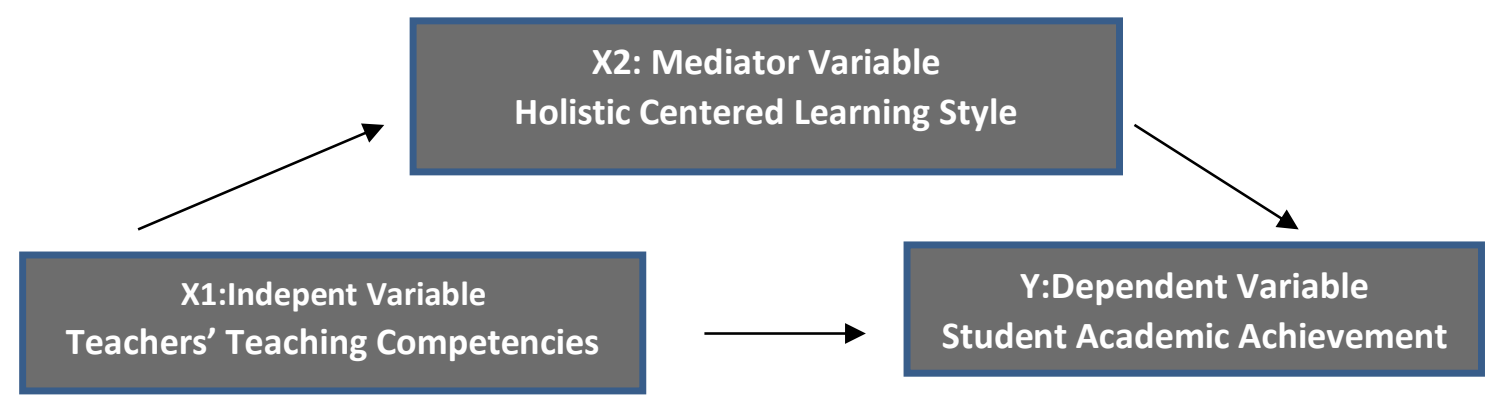

Figure2. Mediation in Causal framework model 


\section{RESEARCH DESIGN AND STYLEOLOGY}

\section{Research Design and Sampling}

The study employed quantitative style involving questionnaires instrument for 219 teachers' and 350 students' from chosen excellent SABK and SMKA secondary school. The respondent validity is measured by using Krejcie \& Morgan (1970). The questionnaire design (quantitative) proposed is the most appropriate style to collect data from the questionnaire that was built. The instrument involved three parts (1) Data Demography Respondents/ teachers, (2) teacher competency adopt and adapt from Murcia et al (2015), (3) Holistic Centered Learning activities using multiple Intelligent learning style: Visual, auditory, verbal, physical, logical, social and solitary modify version by researcher (Whitley S.,2003), (4) Data for Student Academic performance Result of SPM on year 2015 and 2016. The questionnaire built in dual- languages in Bahasa Malaysia and English language. A ten point Likert scale format was used as a response to the statements. The ten-point Likert scale is used because its accuracies in assess belief or opinion in closed questionnaires (Zainudin,2015).

\section{Data Analysis}

All data in the questionnaire will be keyed in using SPSS software to key in data for descriptive statistics (percentage, mean, median, mode), measures of central tendency (range, standard deviation, variance), the forecasting (linear regression, regression), SEM AMOS Software programs is used to do factor analysis (EFA, CFA). Data question is built to answer the research question and to prove in accepting or rejecting the research hypothesis made in the study.

\section{The Confirmatory Factor Analysis (CFA)}

Confirmatory Factor Analysis is to validate the measurement model of all latent constructs involved in the study. The validation procedures in CFA were assessed in unidimensionality, Validity, and Reliability of all constructs (Zainudin, 2015; Tabahcnick \& Fidell, 2007). The result report using of Pooled CFA is much efficient than individual CFA (Chong et. al., 2014) because it can avoid the model identification problem especially if some of the constructs have less than four measuring items per construct (Kashif et al, 2015; Awang, et. al., 2015). Using this method, all constructs are pooled together and linked using the double-headed arrows to assess the correlation among the constructs. However, its usefulness could not reasonable for the high number of observed and unobserved variable (i.e., latent construct) due to convergence problem (Reinartz et al., 2009). As a result, the individual CFA is carry out for each construct before testing their construct correlation. In this stage, the construct validity and reliability were assessed by inspecting their fitness indexes and factor loading. The recommended value for the factor loadings and construct reliability are 0.60 and 0.70 respectively (Raykov, 1997; MacKinnon, 2008; Awang et. al., 2015).

\section{RESULT AND DISCUSSION}

\section{Teacher Teaching Competencies}

Result shows that the fitness indexes (RMSEA, CFI, TLI, and NFI) appeared in Teacher Teaching Competencies model are satisfied. However, some of the value of factor loadings is below than 0.60 which has potential to reduce the impact of construct reliability and validity. According to 


\section{DEVELOPMENT}

Vol. 8, No. 1, 2019, E-ISSN: 2226-6348 @ 2019 HRMARS

Mackinnon (2008) and Awang et. al. (2015), the recommended value for the factor loading in the model is 0.60 and above. As results, the factor loading below 0.60 should be dropped from the model in order to increase the impact of the construct reliability and validity.

In this case, the two subscales of Planning and Result did not have any low factor loading problem indicating that these subscales could retained for the subsequent analysis. Meanwhile, subscale of develop have five items below than 0.60 of factor loading. To follow the guidelines by the previous literatures, those five items are dropped simultaneous and re-run the same analysis on this new specified model to obtain the result as follows.

Hair et. al., (2017) suggested the study should report at least one index from each of the three model fit namely Absolute Fit, Incremental Fit and Parsimonious Fit in order to prove construct validity. From this table, we can see all fitness indexes have achieved the required level. Thus the measurement model has achieved the construct validity (Zainudin, 2015). The study needs to report the Composite Reliability (CR) which indicate the reliability of the construct and the Average Variance Extracted (AVE) which indicate the convergent validity of the construct. The threshold value for CR is 0.6 or higher while the threshold value of AVE has to be 0.5 or higher.

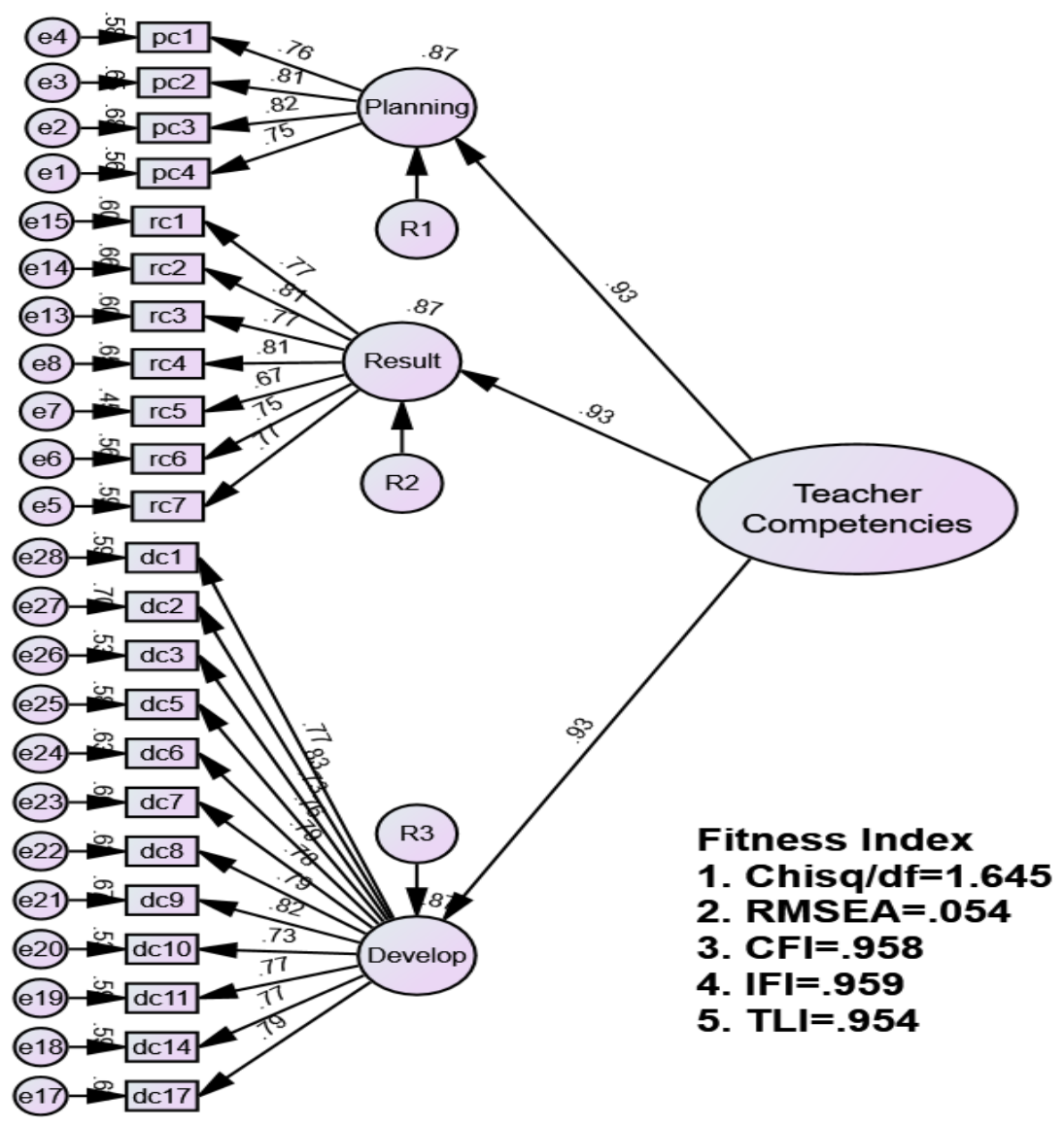

Figure 3.: Model for Teacher Competencies in Teaching 
INTERNATIONAL JOURNAL OF ACADEMIC RESEARCH IN PROGRESSIVE EDUCATION AND

DEVELOPMENT

Vol. 8, No. 1, 2019, E-ISSN: $2226-6348$ @ 2019 HRMARS

Table 2: The summary of Fitness Indexes

\begin{tabular}{llll}
\hline Name of category & Name of index & Index value & Comments \\
\hline Absolute fit & RMSEA & 0.054 & The required level is achieved \\
\hline Incremental fit & CFI & 0.958 & The required level is achieved \\
& TLI & 0.954 & The required level is achieved \\
& IFI & 0.959 & The required level is achieved \\
\hline Parsimonious fit & Chisq/df & 1.645 & The required level is achieved \\
\hline
\end{tabular}

Table 3:Data on CR and AVE

\begin{tabular}{ccc}
\hline & CR & AVE \\
\hline Teacher Teaching Competencies & .951 & .865 \\
\hline
\end{tabular}

The results in this table shows all Composite Reliability (CR) and Average Variance Extracted (AVE) exceeds the threshold value of 0.6 and 0.5 respectively which indicate the convergent validity and composite reliability of all main constructs in the model (Zainudin, 2015).

\section{Holistic Centered Learning}

Result in figure 4 shows that the fitness indexes (RMSEA, CFI, TLI, and NFI) appeared in Holistic Centered model is satisfied. However, some of the value of factor loadings is below than 0.60 which has potential to reduce the impact of construct reliability and validity. According to MacKinnon (2008) and Zainuddin et al., (2015), the recommended value for the factor loading in the model is 0.60 and above. As results, the factor loading below 0.60 should be dropped from the model in order to increase the impact of the construct reliability and validity.

In this case, the five subscales of Verbal, Aural, Physical, Visual and Logical did not have any low factor loading problem indicating that these subscales could retained for the subsequent analysis. Meanwhile, the two subscale of Social and Solitary have four and three items below than 0.60 of factor loading respectively. To follow the guidelines by the previous literatures, those seven items ( 4 items from Social and 3 items from Solitary) are dropped simultaneously and rerun the same analysis on this new specified model to obtain the result as follows.

Hair et al., (2017) suggest the study should report at least one index from each of the three model fit namely Absolute Fit, Incremental Fit and Parsimonious Fit in order to prove construct validity. From this table, we can see all fitness indexes have achieved the required level. Thus the measurement model has achieved the construct validity (Zainudin, 2015). The study needs to report the Composite Reliability (CR) which indicate the reliability of the construct and the Average Variance Extracted (AVE) which indicate the convergent validity of the construct. The threshold value for CR is 0.6 or higher while the threshold value of AVE has to be 0.5 or higher. 


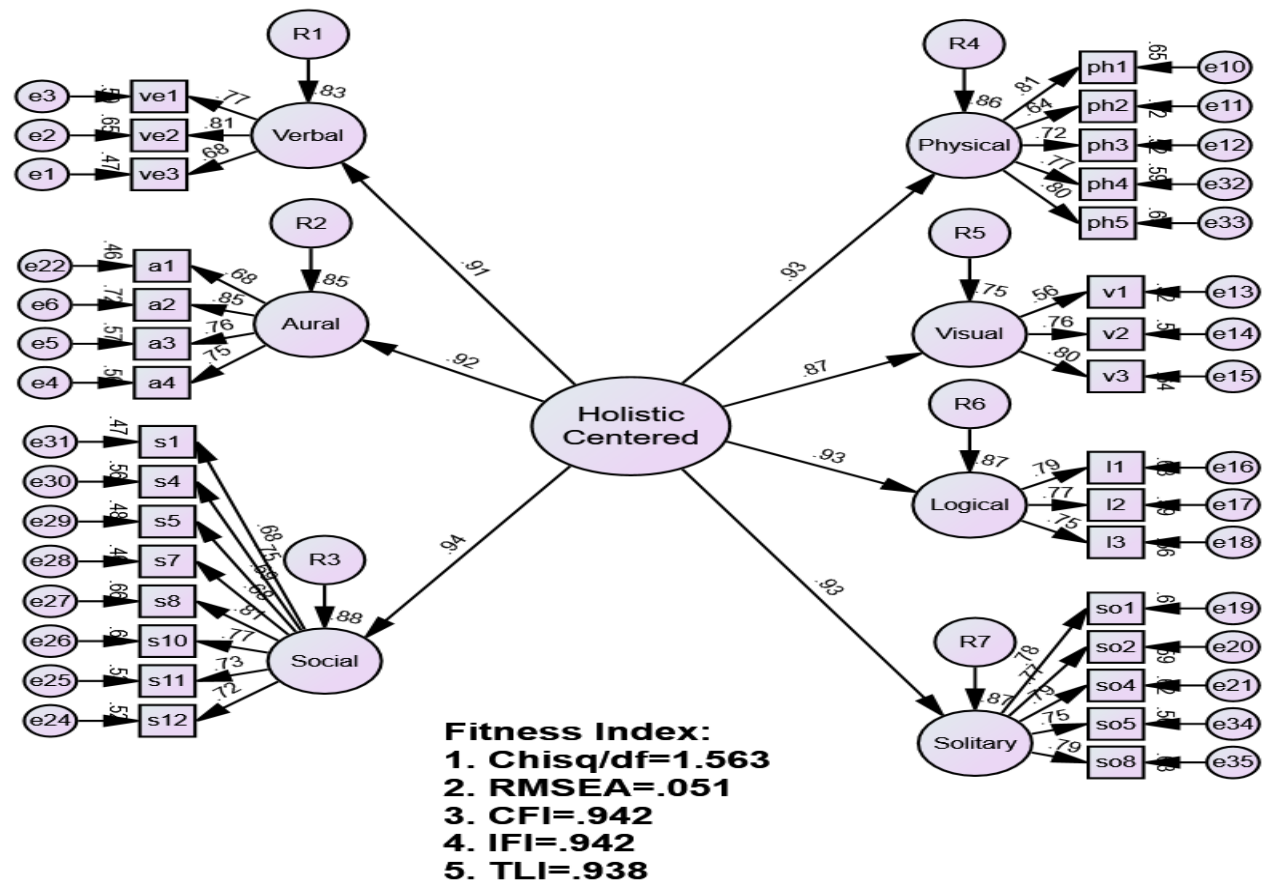

Figure 4: Final Model for Holistic Centered Learning

Table 4: The summary of Fitness Indexes

\begin{tabular}{llll}
\hline Name of category & Name of index & Index value & Comments \\
\hline Absolute fit & RMSEA & 0.051 & The required level is achieved \\
\hline Incremental fit & CFI & 0.942 & The required level is achieved \\
& TLI & 0.938 & The required level is achieved \\
& IFI & 0.942 & The required level is achieved \\
\hline Parsimonious fit & Chisq/df & 1.563 & The required level is achieved \\
\hline
\end{tabular}

Table 5: Data on CR and AVE

\begin{tabular}{lrr}
\hline & \multicolumn{1}{c}{ CR } & \multicolumn{2}{c}{ AVE } \\
\hline Holistic Centered & .844 & .974 \\
\hline
\end{tabular}

The results in this table 5 shows all Composite Reliability (CR) and Average Variance Extracted (AVE) exceeds the threshold value of 0.6 and 0.5 respectively which indicate the convergent validity and composite reliability of all main constructs in the model (Zainudin, 2015).

\section{Student Academic Performance}

Hair et.al., (2017) suggested a study should report at least one index from each of the three model fit namely Absolute Fit, Incremental Fit and Parsimonious Fit in order to prove construct validity. From this table, we can see all fitness indexes have achieved the required level. Thus the measurement model has achieved the construct validity (Zainudin, 2015). The study needs to report the Composite Reliability (CR) which indicate the reliability of the construct and the 
Vol. 8, No. 1, 2019, E-ISSN: 2226-6348 @ 2019 HRMARS

Average Variance Extracted (AVE) which indicate the convergent validity of the construct. The threshold value for CR is 0.6 or higher while the threshold value of AVE has to be 0.5 or higher.

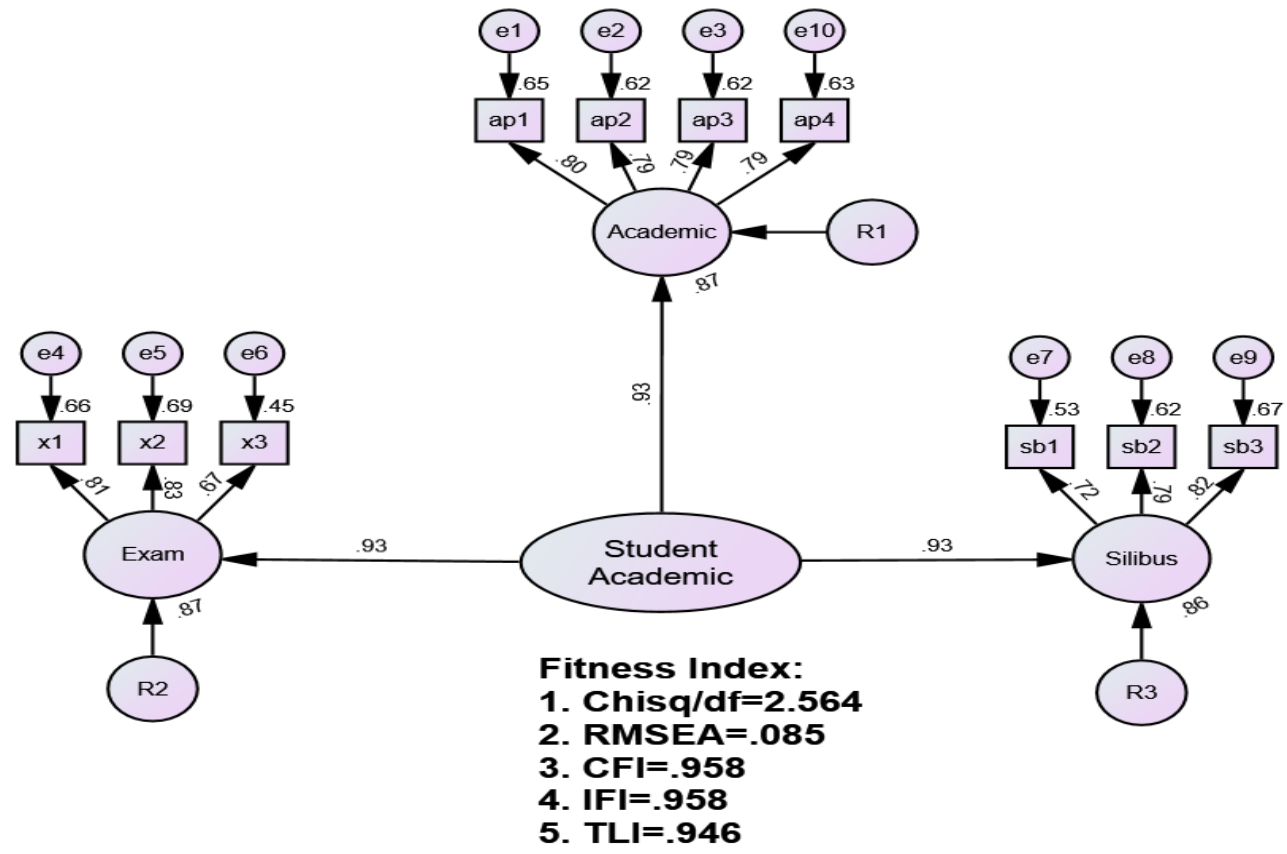

Figure 5: student academic construct

Table 6: The Summary Of Fitness Indexes

\begin{tabular}{llll}
\hline Name of category & Name of index & Index value & Comments \\
\hline Absolute fit & Rmsea & 0.085 & The required level is achieved \\
\hline Incremental fit & $\mathrm{Cfi}$ & 0.958 & The required level is achieved \\
& $\mathrm{Tli}$ & 0.946 & The required level is achieved \\
& $\mathrm{Ifi}$ & 0.958 & The required level is achieved \\
\hline Parsimonious fit & Chisq/df & 2.564 & The required level is achieved \\
\hline
\end{tabular}

Table 7: Data on CR and AVE

\begin{tabular}{lcc}
\hline & CR & AVE \\
\hline Student academic & .951 & .865 \\
\hline
\end{tabular}

The results in this table 7 shows all composite reliability (CR) and average variance extracted (AVE) exceeds the threshold value of 0.6 and 0.5 respectively which indicate the convergent validity and composite reliability of all main constructs in the model (Zainudin, 2015).

\section{Pooled Confirmatory Factor Analysis (PCFA)}

As aforementioned, the analysis of pooled CFA was carried out on this study to assess the construct correlations which is one of the important parts in determining the discriminant validity. The discriminant validity is used to determine of how differ the role for each construct in contributing the impact of the research project. According Fornell \& Larcker (1981) and 


\section{DEVELOPMENT}

Vol. 8, No. 1, 2019, E-ISSN: 2226-6348 @ 2019 HRMARS

Voorhoes et al. (2016), the establishment of the discriminant validity can be done by the comparison of square root AVE and construct correlation. Now, the items for each subscale was aggregated in a same variable that representatives for the whole subscales. The use of this approach is acceptable to minimize the excessive number of items and construct. Bearing in mind that the items with high factor loading (>.60) are allowed for the computational approach.

\section{Pooled CFA}

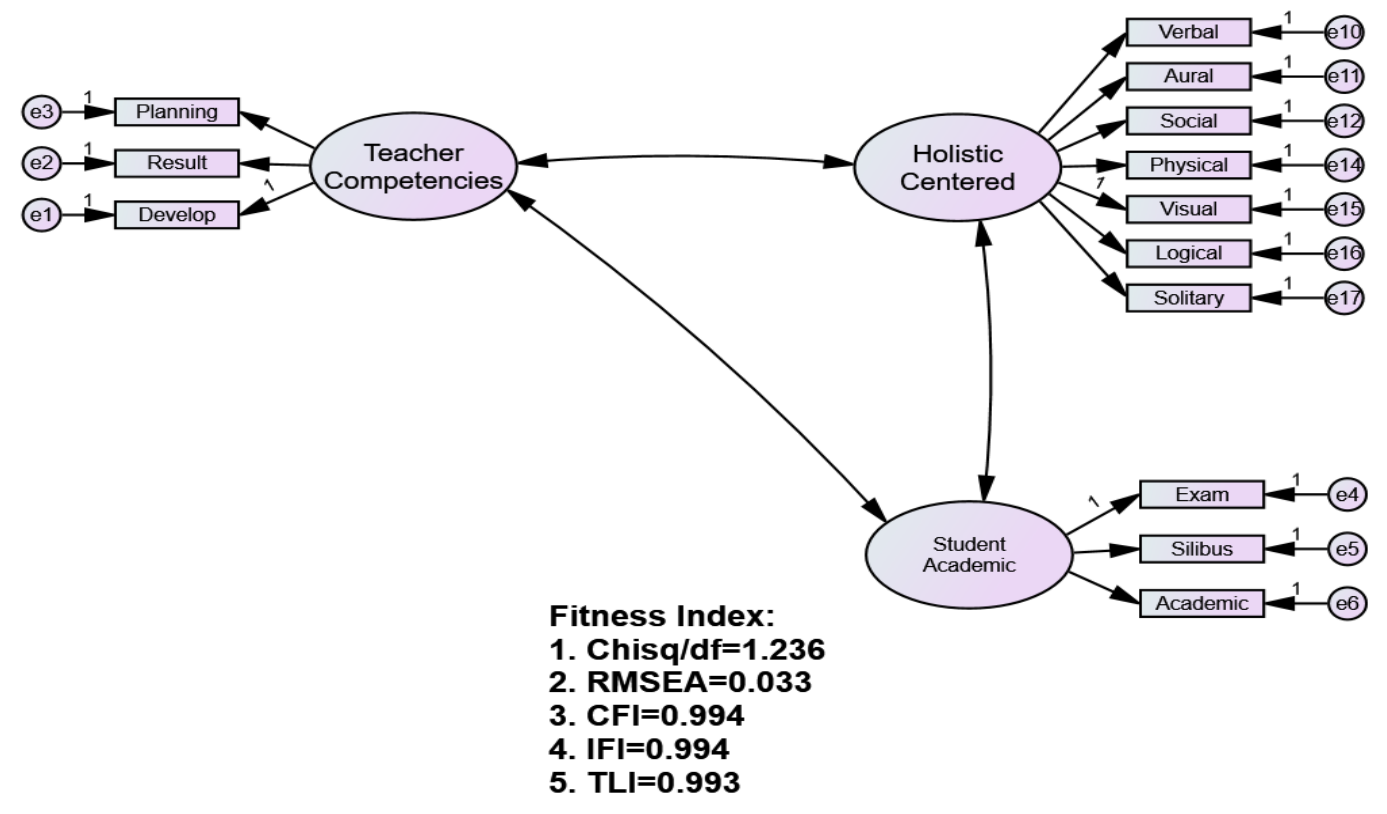

Figure 6: Standardized Estimates, Structural Equation Model of Research

Hair et al. (2017) suggest the study should report at least one index from each of the three model fit namely absolute fit, incremental fit and parsimonious fit in order to prove construct validity. From this table, we can see all fitness indexes have achieved the required level. Thus the measurement model has achieved the construct validity (Zainudin, 2015). The study needs to report the composite reliability (CR) which indicate the reliability of the construct and the average variance extracted (AVE) which indicate the convergent validity of the construct. The threshold value for $C R$ is 0.6 or higher while the threshold value of AVE has to be 0.5 or higher.

The results in table 9 shows all composite reliability (CR) and average variance extracted (AVE) exceeds the threshold value of 0.6 and 0.5 respectively which indicate the convergent validity and composite reliability of all main constructs in the model (Zainudin, 2015). 
INTERNATIONAL JOURNAL OF ACADEMIC RESEARCH IN PROGRESSIVE EDUCATION AND

DEVELOPMENT

Vol. 8, No. 1, 2019, E-ISSN: $2226-6348$ @ 2019 HRMARS

Table 8 : The Summary of Fitness Indexes

\begin{tabular}{llll}
\hline Name of category & Name of index & Index value & Comments \\
\hline Absolute fit & Rmsea & 0.033 & The required level is achieved \\
Incremental fit & $\mathrm{Cfi}$ & 0.994 & The required level is achieved \\
& $\mathrm{Tli}$ & 0.993 & The required level is achieved \\
& Ifi & 0.994 & The required level is achieved \\
Parsimonious fit & Chisq/df & 1.236 & The required level is achieved \\
\hline
\end{tabular}

Table 9: Data on CR and AVE

\begin{tabular}{lrr}
\hline & $\mathrm{Cr}$ & Ave \\
\hline Teacher_teaching competencies & 0.960 & 0.888 \\
Student_academic & 0.927 & 0.809 \\
Holistic_centered & 0.963 & 0.787 \\
\hline
\end{tabular}

In the last steps of CFA report, the study needs to assess the discriminant validity of the constructs in order to clarify that they are not redundant of each other. The discriminant validity for the construct is achieved if the correlation among the exogenous constructs in the model does not exceed 0.85 (Zainudin, 2015; Bakar \& Afthanorhan, 2016). The study also needs to develop the discriminant validity index summary for all constructs involved in the model in order to ensure that they are discriminant among each other. The discriminant validity index summary is shown in table 10.

Table 10: Discriminant Validity Index Summary

\begin{tabular}{lccc}
\hline & $\begin{array}{c}\text { Teacher's } \\
\text { Teaching } \\
\text { Competencies }\end{array}$ & $\begin{array}{c}\text { Student } \\
\text { Academic }\end{array}$ & $\begin{array}{c}\text { Holistic } \\
\text { Centered Learning } \\
\text { style }\end{array}$ \\
\hline $\begin{array}{l}\text { Teacher teaching } \\
\text { competencies }\end{array}$ & $\mathbf{0 . 9 4 2}$ & & \\
$\begin{array}{l}\text { Student academic } \\
\text { Holistic centered learning }\end{array}$ & 0.487 & $\mathbf{0 . 9 0 0}$ & \\
style & 0.467 & 0.507 & $\mathbf{0 . 8 8 7}$ \\
\hline
\end{tabular}

The discriminant validity index summary is presented in table 10 . The diagonal values in bold are the square root of the AVE of the respective constructs while other values are the correlation between the respective pair of constructs. The discriminant validity of the respective construct is achieved if the square root of its AVE exceeds its correlation value with other constructs in the model. In other words, the discriminant validity is achieved if the diagonal values (in bold) are higher than any other values in its row and column. The tabulated values meet the threshold of 
INTERNATIONAL JOURNAL OF ACADEMIC RESEARCH IN PROGRESSIVE EDUCATION AND

DEVELOPMENT

Vol. 8, No. 1, 2019, E-ISSN: 2226-6348 @ 2019 HRMARS

discriminant validity. Thus, the study concludes that the discriminant validity for all constructs is achieved.

Finally, the study needs to assess for normality distribution of all items measuring the construct before modeling the structural model and executing sem. Since SEM employs the parametric statistical approach of modeling, the study needs to assess the normality distribution of all accepted items measuring the constructs. According to Kashif et al. (2016), the study only needs to show that the values of skewness for all items do not depart from normality. Thus the absolute skewness values less than 1.0 is acceptable. The assessment of normality distribution for all items is presented in table 11 .

Table 11: Assessment Of Normality

\begin{tabular}{lcccccc}
\hline \multicolumn{1}{c}{ Variable } & Min & Max & Skew & C.r. & Kurtosis & C.r. \\
\hline Solitary & 3.875 & 8.125 & .405 & 2.446 & .673 & 2.033 \\
Logical & 3.333 & 8.000 & .186 & 1.122 & .301 & .909 \\
Visual & 3.333 & 7.667 & .132 & .798 & .366 & 1.105 \\
Physical & 3.000 & 7.200 & .301 & 1.818 & .187 & .564 \\
Social & 3.417 & 6.917 & .322 & 1.945 & .165 & .500 \\
Aural & 3.500 & 7.750 & .368 & 2.223 & .132 & .399 \\
Verbal & 3.667 & 8.667 & .129 & .781 & -.205 & -.620 \\
Academic & 2.750 & 7.250 & -.093 & -.561 & -.281 & -.850 \\
Silibus & 4.000 & 9.000 & .007 & .042 & -.158 & -.477 \\
Exam & 3.333 & 8.667 & .058 & .353 & .125 & .378 \\
Planning & 5.250 & 10.000 & .056 & .340 & -.335 & -1.011 \\
Result & 2.714 & 7.571 & -.186 & -1.121 & -.010 & -.029 \\
Develop & 3.765 & 7.471 & -.145 & -.876 & -.254 & -.768 \\
\hline Multivariate & & & & & \multirow{2}{*}{1.389} & .404 \\
\hline
\end{tabular}

The normality assessment is made by assessing the measure of skewness for every item. The absolute value of skewness of 1.0 or lower indicates the data is normally distributed. However, for SEM using the maximum likelihood estimator like Amos is fairly robust to skewness greater than 1.0 in absolute value if the sample size is large and the critical region (CR) for the skewness does not exceed 8.0. Normally the sample size of 200 or more is considered large enough even though the data distribution is slightly non-normal. Thus, the researcher could precede into further analysis even though the value of skewness up to 1.5. The normality assessment also is based on multivariate kurtosis statistic. However, SEM using maximum likelihood estimator (MLE) is also robust to kurtosis violations of multivariate normality as long the sample size is large and the critical region for the kurtosis does not exceed 7.0. 


\section{Testing the Mediation Effect}

The current study contained one research hypothesis that need for the assessment of indirect effect. The mediator construct for this study is holistic centered. The previous chapter stated that the holistic centered mediates the relationships between teacher competencies and student academic. To do so, this study want to apply two approaches namely step-wise (Baron \& Kenny, 1986) and bootstrapping (Preacher \& Hayes, 2008) approach. Both approaches are recognized as prominent tool for assessing the mediation effect. The use of bootstrapping approach is to proven the results obtained from step-wise approach which could be more convinced. The assessment for the mediating model is begun with the step-wise approach followed by bootstrap approach.

\section{Indirect effect:}

$A=$ teacher competencies on holistic centered $=0.47^{* * *}$

$\mathrm{B}=$ holistic centered on student academic $=0.28 * * * \mathrm{~A} \times \mathrm{b}=0.47 \times 0.28=0.1316^{* * *}$

Test:

The result showed that the mediation is occurring in the model due to significant indirect effect. In order to compute the $z$-test, the value of indirect effect $(a \times b)$ should be significant different from zero or must higher than the direct effect $\left(c^{\prime}\right)$.

\section{Direct effect:}

$C^{\prime}=$ teacher competencies on student academic $=0.23^{* * *}$

Test:

$A \times b=0.1316<0.23$. It shows that the value of indirect effect is smaller than the value of direct effect although the significant indirect are shown in the result. Therefore, this model needs to re-analyzed by determining the value of direct effect when the mediator excluded from the model (lacobucci et. al., 2007; Awang, 2015; Baron \& Kenny, 1986). Accordingly, the partial mediation is existing when the direct effect increased after the model is estimated without the presence of mediation construct (holistic centered learning style).

\section{Bootstrapping Approach}

The analysis of mediation model with bootstrap is available in AMOS package. This study used bootstrap maximum likelihood estimator due to its consistency and efficiency solutions. The results for the standardized and two-tail between direct and indirect effect are shown as follows.

Table 12: Standardized Direct Effects (group number 1 - default model)

\begin{tabular}{lcl}
\hline & $\begin{array}{c}\text { Teacher teaching } \\
\text { competencies }\end{array}$ & $\begin{array}{l}\text { Holistic_centered } \\
\text { learning style }\end{array}$ \\
\hline Holistic_centered & .473 & .000 \\
learning style & .233 & .278 \\
Student_academic & .230 \\
\hline
\end{tabular}


INTERNATIONAL JOURNAL OF ACADEMIC RESEARCH IN PROGRESSIVE EDUCATION AND DEVELOPMENT

Vol. 8, No. 1, 2019, E-ISSN: $2226-6348 @ 2019$ HRMARS

Table 13: Standardized Direct Effects two tailed significance (bc) (group number 1 - default model)

\begin{tabular}{lcc}
\hline & $\begin{array}{c}\text { Teacher teaching } \\
\text { competencies }\end{array}$ & $\begin{array}{c}\text { Holistic_centered } \\
\text { learning style }\end{array}$ \\
\hline Holistic_centered learning style & .002 & $\ldots$ \\
Student_academic & .002 & .002 \\
\hline
\end{tabular}

Table 14: Standardized Indirect effects (group number 1 - default model)

\begin{tabular}{lcc}
\hline & Teacher teaching competencies & $\begin{array}{c}\text { Holistic_centered } \\
\text { learning style }\end{array}$ \\
\hline Student_academic & .132 & .000 \\
\hline
\end{tabular}

Table 15: Standardized Indirect Effects - two tailed significance (bc) (group number 1 - default model)

\begin{tabular}{lcc}
\hline & Teacher teaching competencies & $\begin{array}{l}\text { Holistic_centered } \\
\text { learning style }\end{array}$ \\
\hline Student_academic & .001 & $\ldots$ \\
\hline
\end{tabular}

Table 16 : The Summary of Direct and Indirect Effect (Teacher Competencies on Student Academic Through Holistic Centered learning style)

\begin{tabular}{lcc}
\hline & Indirect effect & Direct effect \\
\hline Bootstrapping estimate & .132 & .233 \\
Bootstrapping p-value & .001 & .002 \\
Result & Significant & Significant \\
\hline
\end{tabular}

Table 17 : Mediation Result

Type of mediation Partial mediation

Based on the finding revealed, the result of mediation using bootstrap approach is consistent with the previous one. Results, the partial mediation truly exists in the model. It should be note that the partial mediation can be defined when the indirect and direct effects are significant. $\mathrm{H}$ is supported.

Table 18: Hypotheses Summary Result

\begin{tabular}{llc}
\hline No & \multicolumn{1}{c}{ The main hypotheses statement in the research } & Result \\
\hline $\mathrm{H}$ & $\begin{array}{l}\text { Holistic centered learning style }(\mathrm{HCL}) \text { mediates the relationship } \\
\text { between teacher competencies teaching skill (TCTS) and student } \\
\text { academic performance (SP). }\end{array}$ & Supported \\
\end{tabular}




\section{CONCLUSION AND IMPLICATIONS}

Thus the study concludes $\mathrm{H}$ : holistic centered learning style mediates the relationship between teacher's teaching competencies teaching skill and student academic performance. Apparently, the study fills the gaps $\mathrm{H}$ : using mediator effect to link holistic centered learning with teachers' teaching competencies and student academic performance.

The nature of teaching about teaching demands skills, expertise and knowledge should not be taken for granted. Thus, research highlighting issues regarding up skill standards for teacher educators are needed and should be encouraged, so that such skills, style, expertise and knowledge can be cautiously investigated and articulated as the teaching skills can be assessed. Furthermore, by doing so, professional development opportunities for skilled teacher will rise and their impact within the profession will advance in current of education in $21^{\text {st }}$ century and full fill Malaysian national NKRA blueprint (2013-2025), and the education system producing excellent human resource with equipped soft skill and knowledge across disciplinary.

\section{ACKNOWLEDGEMENT}

We express our deepest gratitude to Research Management, Innovation \& Commercialization Centre and Universiti Sultan Zainal Abidin in Malaysia for supporting our academic work. We also thank Ministry of Education for funding the PhD student under My Brain15 doctoral program.

\section{CORRESPONDING AUTHOR}

Dr. Rahimah Embong, PhD. is Associate Professor at Department of Education, Dakwah \& Islamic Civilization at Faculty of Islamic Contemporary Studies as well as Deputy Dean (Student Affairs \& Alumi), Faculty of General Studies \& Advanced Education at Universiti Sultan Zainal Abidin (UniSZA), Gong Badak Campus, 21300 Kuala Nerus. Terengganu, Malaysia.

Email: rahimahembong@unisza.edu.my

\section{REFERENCES}

Abdullah, I. (2004). Pembelajaran Berpusatkan Pelajar Dan Kaitannya Dengan Pembangunan Diri Dan Peluang Pekerjaan. Seminar Penyelidikan Pendidikan Guru Peringkat Kebangsaan 2004, 8 - 9 September, City Bayview Hotel, Langkawi, Kedah.

Abdul Kadir, S. (2002). Perbandingan pembelajaran koperatif dan tradisional terhadap prestasi, atribusi pencapaian, konsep kendiri akademik dan hubungan sosial dalam pendidikan perakaunan. Universiti putra malaysia: tesis doktor falsafah.

Aslanian, C. \& Giles, N. G. (2009). Hindsight, Foresight, Insight: Understanding Adult Learning Trends to Predict Future Opportunities. Retrieved June 9, 2009, From Http://Www.Aslaniangroup.Com/

Bakar, A. A., \& Afthanorhan, A. (2016). Confirmatory Factor Analysis On Family Communication Patterns Measurement. Procedia-Social And Behavioral Sciences, 219, 33-40.

Bainter, S. A., \& Bollen, K. A. (2014). Interpretational confounding or confounded interpretations of causal indicators? Measurement: Interdisciplinary Research and Perspectives, 12(4), 125-140. doi:10.1080/15366367.2014.968503

Baron, R. M., \& Kenny, D. A. (1986). The Moderator-Mediator Variable Distinction In Social 
INTERNATIONAL JOURNAL OF ACADEMIC RESEARCH IN PROGRESSIVE EDUCATION AND

DEVELOPMENT

Vol. 8, No. 1, 2019, E-ISSN: 2226-6348 @ 2019 HRMARS

Psychological Research: Conceptual, Strategic, And Statistical Considerations. Journal Of Personality And Social Psychology, 51, 1173-1182.

Chedzoy, S., M. \& Burden, R.L. (2007) Marking Time Or Moving on Research In Education, 77, P.31-45.

Chong, E.E., Nazim. A.,\& Ahmad, S. B. (2014). A Comparison Between Individual And Pooled Confirmatory Factor Analysis: An Analysis Of Library Service Quality, , A Case Study At A Public University In Terengganu. International Journal Of Engineering Science And Innovation Technology, 3(10), 110-116

Dirkx, J. M. \& Prenger, S. M. (1997). A Guide for Planning And Implementing Instruction For Adults. San Francisco: Jossey-Bass.

Finelli, S., Loudin, M., \& Berndt, R. (2014). Technology In Today's K-12 Classroom. Presentation Made At The Baldwin Wallace University Alumni Weekend, Baldwin Wallace University, Berea, Oh, May 17.

Fornell, C., \& Larcker, D. F. (1981). Evaluating Structural Equation Models With Unobservable Variables And Measurement Error. Journal Of Marketing Research, 39-50.

Gardner, H. (1983). Frames of Minds, New York: Basic Books

Grove, N., \& Bretz, S. L. (2007). Chemx: An Instrument To Assess Students"Cognitive Expectations For Learning Chemistry. Journal Of Chemical Education, 84(9), 15241529.

Guzman, J. (2003): "Achievement in Youth With Disabilities", Entrepreneurship, Servicio De Publicaciones UAB, Bellaterra (Barcelona)

Harashim, L. (2011). Chapter Two: Historical Overview of Learning And Technology. Retrieved From http://Lindaharasim.Com/Sfu-Courses/Cmns-453/Chapter-Two-HistoricalOverviewof-Learning-And-Technology/.Accessed On 5/6/15

Hartini, N. (2010). Kesediaan Guru Dalam Perlaksanaan Kemahiran Berfikir Dalam Pengajaran Dan Pembelajaran Pendidikan Muzik Di Sekolah Rendah.(Unpublished Doctoral Dissertation) Universiti Pendidikan Sultan Idris.

Hair Jr, J. F., Babin, B. J., \& Krey, N. (2017). Covariance-Based Structural Equation Modeling. Journal Of Advertising: Review 1-15, 163-177.

lacobucci, D., Saldanha, N., \& Deng, X. (2007). A Meditation On Mediation: Evidence That StructuralEquations Models Perform Better Than Regressions. Journal Of Consumer Psychology, 17(2), 139-153.

Imel, S. (1991). Collaborative Learning In Adult Education. Eric Clearinghouse On Adult Career And Vocational Education, No. 113. Retrieved June 5, 2009, From Www/Ericdigests.Org/Pre-9220/Adult.Htm

Jayaron, J. \& Mohammed, J. (2016) A Pedagogical Perspective On Promoting English As A Foreign Language Writing Through Online Forum Discussions. English Language Teaching; Vol. 9, No. 2; 2016 Issn 1916-4742 E-Issn 1916-4750 Published By Canadian Center Of Science And Education.

Pushpalatha A/P Sivamugam. (2006). Elemen Kemahiran Berfikir Aras Tinggi (Kbat) Dalam Instrumen Pentaksiran. Putrajaya: Kementerian Pendidikan Malaysia.

Kashif, M., Awang, Z., Walsh, J., \& Altaf, U. (2015). I'm Loving It But Hating Us: Understanding Consumer Emotions And Perceived Service Quality Of Us Fast Food Brands. British Food Journal, 117(9), 2344-2360.

Kashif, M., Samsi, S. Z. M., Awang, Z., \& Mohamad, M. (2016). Exq: Measurement Of Healthcare 
INTERNATIONAL JOURNAL OF ACADEMIC RESEARCH IN PROGRESSIVE EDUCATION AND

DEVELOPMENT

Vol. 8, No. 1, 2019, E-ISSN: 2226-6348 @ 2019 HRMARS

Experience Quality In Malaysian Settings: A Contextualist Perspective. International Journal Of Pharmaceutical And Healthcare Marketing, 10(1), 27-47.

Katharina S,N (2016). Effective Classroom- Management\& Positive Teaching. English Language Teaching; Vol. 9, No. 1; 2016 Issn 1916-4742 E-Issn 1916-4750

Krejcie, R. V. \& Morgan, D. W. (1970). Determining Sample Size For Research. Education And

Psychological Measurement, 30: 607-610. Http://Opa.Uprrp.Edu/Invinsdocs/Krejcieandmorgan.Pdf

National NKRA. (2013-2025) Rancangan Malaysia Ke-10. Kuala Lumpur: http://www.Moe.Gov.My/Images/Dasar-Kpm/Articlefile_File_003108.Pdf. Accessed 25.6.2015

Norazila, A.A., Hong, K. S. Fitri S.M., Songan, P. \& Noweg, G. T. (2010). Brave New World For University Educators: Effects Of Pedagogical Training On Teaching At Higher Education Level. Paper Presented At The Third Regional Conference Ion Engineering Education And Research In Higher Education, 7-9 June, 2010, Kuching, Sarawak, Malaysia.

Mackinnon, D. P. (2008). Introduction To Statistical Mediation Analysis. New York, NY: Routledge. Murcia J. A.M. \& Silveira, T. (2015). Questionnaire Evaluating Teaching

Competencies In The University Environment. Evaluation Of Teaching Competencies In The University. Journal Of New Approaches In Educational.

Preacher, K. J., \& Hayes, A. F. (2008). Asymptotic and Resampling Strategies For Assessing And Comparing Indirect Effects In Multiple Mediator Models. Behavior Research Methods, 40(3), 879-891

Raykov, T. (1997). Estimation Of Composite Reliability For Congeneric Measures. Applied Psychological Measurement, 21(2), 173-184.

Reinartz, W., Haenlein, M., \& Henseler, J. (2009). An Empirical Comparison Of The Efficacy Of Covariance-Based And Variance-Based Sem. International Journal Of Research In Marketing, 26(4), 332-344.

Rohaty, M. (2000). Preschool Teaching Strategies: Towards Better Learning And The Maximisation Of The Child's Potential. International Conference On Teaching and Learning, 592-595.

Slavin, R. E. (2003). Educational Psychology: Theory and Practice. 7th Ed. New York : Ablongman Ssemugabi, S. \& De Villiers, R., (2007). A Comparative Study of Two Usability Evaluation Methods Using Web-Based E-Learning Application, In Proceedings Of The 2007 Annual Research Conference of The South African Institute Of Computer Scientists And Information Technologists On It Research In Developing Countries, Acm Press, New York, USA.

Tabachnick, B. G., \& Fidell, L. S. (2007). Multivariate Analysis of Variance And Covariance. Using Multivariate Statistics, 3, 402-410

Taskinsoy, J.(2012). "Leap Into Student-Centered Learning (SCL) Paradigm", Universiti

Malaysia Sarawak,UNIMAS, INSIGHT, Volume 17, pp.4-6

Tobias, S. \& Duffy, T. M. (2009). Constructivist Instruction: Success Or Failure?. New York: Taylor \& Francis. Isbn 9780415994231.

Voorhoes, C. M., Brady, M. K., Calantone, R., \& Ramirez, E. (2016). Discriminant Validity Testing In Marketing: An Analysis, Causes for Concern, And Proposed Remedies. Journal of The Academy of Marketing Science, 44(1), 119-134. 
INTERNATIONAL JOURNAL OF ACADEMIC RESEARCH IN PROGRESSIVE EDUCATION AND

DEVELOPMENT

Vol. 8, No. 1, 2019, E-ISSN: 2226-6348 @ 2019 HRMARS

Whiteley, S. (2003), Memletics Accelerated Learning Manual: Discover The High Performance Learning System

That Improves Your Memory and Helps You Leran Faster. Isbn 0975117424.

Zamri, M. (2012). Inovasi $p \& p$ dalam pendidikan. Tanjong Malim: Penerbit Universiti Pendidikan Sultan Idris.

Zajac, M. (2009) "Using Learning Styles to Personalize Online Learning", Campus-Wide Information Systems, Vol. 26 Issue: 3, Pp.256-265, https://Doi.Org/10.1108/10650740910967410.

Zainudin, A. (2015). Sem Made Simple: A Gentle Approach to Learning Structural Equation 'Modeling. Bangi: MPWS Publication

Zainudin, A., Z., Afthanorhan, A., Mohamad, M., \& Asri, M. A. M. (2015). An Evaluation Of Measurement Model For Medical Tourism Research: The Confirmatory Factor Analysis Approach. International Journal Of Tourism Policy, 6(1), 29-45. 